\title{
Thiocyclam-Induced Reproductive Toxicity, Oxidative Stress and Genomic DNA Damage in Testicular Tissues of Rats: Protective Effects of Green Tea Extract
}

\author{
Amr A Abd Allah ${ }^{1}$, Eman A Ibrahim ${ }^{2}$, Eldesoki S Ibrahim ${ }^{3}$, Naglaa F Mahmoud ${ }^{4}$, Mostafa M Afify ${ }^{\star}$ \\ ${ }^{1}$ Mammalian Toxicology Department, Central Agricultural Pesticides Lab. (CAPL), Agricultural Research Center, Ministry of Agriculture, Dokki, Giza, Egypt \\ ${ }^{2}$ Plant Biochemistry Department, National Research Centre (NRC), 33 EL Bohouth st. (former EL Tahrir st.), P.O. 12622, Dokki, Giza, Egypt \\ ${ }^{3}$ Economic Entomology and Pesticides Department, Faculty of Agriculture, Cairo University, Gamha Street, P.O. 12613, Giza, Egypt \\ ${ }^{4}$ Forensic Medicine and Clinical Toxicology Department, Faculty of Medicine, Cairo University, Al-Saray Street, P.O. 11956, El Manial, Cairo, Egypt \\ ${ }^{5}$ Forensic Medicine and Clinical Toxicology Department, Faculty of Medicine, Beni-Suef University, P.O.62511, Beni-Suef, Egypt
}

"Corresponding author: Afify MM, Forensic Medicine and Clinical Toxicology, Faculty of Medicine, Beni-Suef University, Egypt, Tel: 00201273206767; E-mail: drafify78@yahoo.com

Received: April 23, 2018; Accepted: April 28, 2018; Published: April 30, 2018

Copyright: ( 2018 Afify MM. This is an open-access article distributed under the terms of the Creative Commons Attribution License, which permits unrestricted use, distribution, and reproduction in any medium, provided the original author and source are credited.

\begin{abstract}
Thiocyclam is a broad-spectrum nereistoxin analogue insecticide which widely used for agricultural applications. The aim of this study is to investigate the protective effects of green tea (as a principal source of antioxidants) on Thiocyclam-Induced Reproductive Toxicity, Oxidative Stress and Genotoxicity in adult Male Rats. Forty adult male rats were randomly assigned into four groups: control, Thiocyclam (ThC, $15.98 \mathrm{mg} / \mathrm{kg} \mathrm{b.w.),} \mathrm{green} \mathrm{tea} \mathrm{extract} \mathrm{(GTE,}$ $2 \% \mathrm{w} / \mathrm{v}$ as the sole beverage) and (ThC+GTE) group. After 65 days of treatment, blood samples and testicular tissue were collected for measuring the oxidative stress parameters, testosterone level and DNA damage, whereas the reproductive organs were weighed, and Semen analysis and testicular histopathological studies was done. The results revealed that Thiocyclam administration induce a significant reduction in sperm count, sperm motility as well as testosterone level, while increased sperm abnormality. In addition to increased testicular tissue Malondialdehyde (MDA), reduced GSH content and testicular DNA damage evidenced by comet assay. The histological examination of testes revealed degenerative change and disorganization of seminiferous tubules with incomplete spermatogenesis. On the contrary, GTE played a potential protective effect against Thiocyclam induced oxidative stress as well as alleviate the reproductive toxicity by improving the oxidative status, decrease oxidative DNA damage, improving semen characteristics and protective effect against testicular damage, highlighting the protective and therapeutic potentiality of green tea against pesticide-induced reproductive toxicity and its health benefits.
\end{abstract}

Keywords: Thiocyclam; Green tea; Oxidative stress; Reproductive toxicity; Lipid peroxidation; DNA damage; Comet assay

\section{Introduction}

Pesticides have become an important component of worldwide agriculture systems over the last decades, allowing for increase crop yields and food production in modern agriculture [1]. However, it has also significantly increasing in the concentration of pesticides in our food and environment, with associated public health hazard including infertility [2]. Exposure to chemical agent including pesticides not only reduces fertility but also induce embryonic and fetal death, birth defects, childhood malignances, and other functional or postnatal deficits [3]. Pesticides obviously have the potentiality to induce reproductive toxicity in animals as well as several Pesticides will know to be affect human reproduction [4]. Furthermore, Pathological effects of several pesticides on the reproductive organs of experimental animals were investigated by many studies [5].

In fact, pesticides are known to induce oxidative stress by free radical's production and generation of reactive oxygen species (ROS) besides releasing of highly reactive metabolites [6]. Many studies performed in humans and animals have implicated oxidative damage as the main mechanism of pesticide chronic toxicity and revealed that pesticide exposure may disturb the oxidative stress homeostasis of the cell by altering antioxidant defense mechanisms [7]. The produced ROS can interact with main biological macromolecules of the cell, eventually damaging membranes, nucleic acids, proteins, lipids, carbohydrates and other tissue. Malondialdehyde (MDA) is considered as a product of lipid peroxidation and widely used in many studies as a biomarker for pesticides-induced oxidative stress. If the body couldn't overcome the increasing rate of induced oxidative stress, it would induce carcinogenic mutations by induction of oxidative DNA damage [8].

Recently, interest has increased in nontoxic naturally occurring compounds with antioxidant activity that can be used to protect humans from oxidative stress damaging effects, to avoid undesired health problems that may be induced from the use of synthetic antioxidants. Green tea is a highly rich source of a specific antioxidant known as polyphenolic flavonoids and the six primary catechin compounds which include catechin, epicatechin, gal-locatechin, epigallocatechin, catechin gallate, epicatechin gallate, gallocatechin gallate, and epigallocatechin gallate [9]. Polyphenols which is a major constituent of Green tea are well known to have a various biological and pharmacological properties with potential health benefits, which include antioxidant, anti-inflammatory, antimicrobial and anti-cancer effects. Some of polyphenolic compounds which extracted from the green tea leaves have been found to be powerful antioxidants activity 
against lipid peroxidation of phospholipid bilayers and against DNA damage [10].

Thiocyclam is a broad-spectrum nereistoxin analogue insecticide which widely produced and used for agricultural in Egypt. This insecticide is an antagonist, blocking cholinergic transmission resulting in paralysis and insect death. This insecticide is metabolically converted to nereistoxin in the insect and interacts with nicotinic acetylcholine receptors [11]. Thiocyclam as other pesticide is known to generate reactive oxygen species (ROS), in addition to green tea is known by its unique antioxidant activities and ability to scavenge ROS and trap hydroxyl, peroxyl and superoxide anion radicals (radical scavenging properties) due to the presence of catechins. Therefore, the objective of our study is to investigate the possible protective effects of Green tea extract against the oxidative stress, DNA damage and reproductive toxicity, induced by Thiocyclam in adult male rats.

\section{Materials and Methods}

\section{Chemicals}

Technical grade Thiocyclam insecticide (2 dimethylaminopropane -1, 3-dithiol analogue) a product of Arysta Life Sciences pesticide company, Japan. Green tea of post-fermented green tea extract produced in Yunnan province. All other chemical compounds were of reagent grades and were obtained from well-known local scientific distributors in Egypt.

\section{Preparation of green tea extract}

Green tea extract was prepared from the dried leaves according to El-Beshbishy [12] method. Briefly, twenty gram of green tea leaves were soaked with one-liter hot boiling water $\left(90^{\circ} \mathrm{C}\right)$ for 5 minutes to obtain a soluble polyphenol dissolved in the used aqueous extract. The cooled solution was filtered to obtain the final $2 \%(\mathrm{w} / \mathrm{v})$ green tea aqueous extract which used as the only drinking source according to Mehana et al. [13]. The Chemical compositions of the Green tea extract; Total phenol, flavonoids and tannins were assayed according to Tambe and Bhambar [14]. Furthermore, the Total antioxidant activity and The ABTS (2,2-azino-bis-(3-ethylbenzthiazoline-6-sulfonic acid) free radical scavenging capacity were assayed according to Prieto et al. [15] and Arnao et al. [16] respectively.

\section{Animals and experimental design}

Healthy male Wister rats weighing $150 \pm 10 \mathrm{~g}$ was obtained from the Animal Breeding House of the Modern Veterinary Office, Giza, Egypt, and retained in good clean plastic cages in the laboratory animal room $\left(23 \pm 2^{\circ} \mathrm{C}\right)$. On standard grain diet, tap water, and daily dark/light cycle $(12 / 12 \mathrm{hrs}$.) the studied animals were acclimatized for 1 week prior to the start of experiments. The experimental work on these rats was performed with Guiding Principles and the approval of the Animal Care and Experimental Committee, Central Agricultural Pesticides Lab. (CAPL), Ministry of Agriculture, Dokki, Giza, Egypt and the international guidelines for care and use of laboratory animals.

A forty-adult male wister rats were randomly assigned into four groups of ten rats as follows:

Group I: untreated rats, served as control (C).

Group II: orally treated with Thiocyclam (ThC) alone at a dose of (15.98 mg/kg b.w.); about 1/20 LD50.
Group III: orally treated with aqueous green tea extract (GTE) as the only drinking fluid at a concentration of $2 \%(\mathrm{w} / \mathrm{v})$.

Group IV: animals were simultaneously given Thiocyclam orally and given GTE as the sole drinking fluid at a concentration of $2 \%(\mathrm{w} / \mathrm{v})$ (ThC+GTE).

The experiment was conducted for 65 consecutive days which is the period necessary to complete a spermatogenic cycle and maturation of sperms in epididymis [17].

\section{Estimation of median lethal dose 50 (LD50)}

Twenty-four mature male rats were orally administered Thiocyclam with different four concentrations $(260.42,312.5,375$ and $450 \mathrm{mg} / \mathrm{Kg})$. Six rats were served as control group throughout the entire experimental period. Mortality was evaluated and counted in the different groups. LD50 was calculated ad follows equation (LD50=Largest dose- $\Sigma \mathrm{axB} / \mathrm{N}$; where $\mathrm{A}$ : the mean of dead rats between two successive doses, B: dose difference between two successive doses, $\mathrm{N}$ : the total number of rat per group) according to Weil [18].

\section{Samples collection and reproductive organs weight}

Body weights were recorded every week during the experimental period and before sacrifice; male reproductive organs (testes, epididymes and seminal vesicles) were weighed, then relative organ weights were calculated. After the completion of the treatment period, Blood samples were withdrawn from the rats under light ether anesthesia by puncturing the retro-orbital venous plexus of the rats with a fine sterilized capillary tube. The collected blood samples were kept for 20 minutes to coagulate at room temperature, and then centrifuged at $600 \times \mathrm{g}$ for $10 \mathrm{~min}$ to separate the sera. The sera were preserved in a deep freezer $\left(-20^{\circ} \mathrm{C}\right)$ until analyzed. The rats were sacrificed by cervical dislocation. Immediately, testicular tissue organs were cryopreserved at $-80^{\circ} \mathrm{C}$ in RPMI 1640 media (w/o L-Glutamine, w/25 mM Hepes) (biowest) Containing 10\% DMSO and 1\% Fetal Calf Serum, until performing for comet assay test. one testicle, epididymes and accessory sex organs were isolated, cleaned from of adhering matters, washed with ice-cold saline solution, weighed and stored at $-70^{\circ} \mathrm{C}$ for the biochemical studies.

\section{Semen characteristics}

Testicular sperm count: Immediately after dissection, one testicle of each rat was placed in $1 \mathrm{~mL}$ phosphate buffer ( $\mathrm{pH}$ 7.4). Tunica albuginea was cut, removed and the remaining semeniferous tubules were mechanically minced by surgical blades in $1 \mathrm{~mL}$ phosphate buffer. The testicular cell suspension was pipetted several times to make a homogenous cell suspension. One drop of the suspension was placed on the "Haemocytometer chamber" (Neub-auer improved, Feinoptik Bad Blankenburg, Germany). Testicular sperm suspension was counted and evaluated as million sperm cells per $\mathrm{mL}$ of suspension under 200X magnification using phase contrast microscope and the sperm were counted manually. Testicular sperm count was calculated according to Uzunhisarcikli et al. [19].

Sperm motility analysis: The sperms were collected as early as possible after a rat was sacrificed. The cauda epididymis was placed in $1 \mathrm{~mL}$ of $37^{\circ} \mathrm{C}$ phosphate buffer saline solution ( $\left.\mathrm{pH} 7.4\right)$ and then cut by surgical blades into approximately one $\mathrm{mm}$ three pieces. The solution was pipetted several times in order to homogenize the sperm suspension solution and then one drop of the suspension was placed 
on a slide, covered by a cover slip, and evaluated under a phase contrast microscope at 200 magnifications. The sperms were classified, on the basis of their motility as "motile" or "immotile". The analysis results of were recorded as percentage of sperm motility [20].

Sperm morphology: Determination of percentage of the morphologically abnormal spermatozoa was done by spreading one drop of the suspension on a clean slide. The slides were stained well with a mixture of $1.67 \%$ eosin and $10 \%$ nigrosin in $0.1 \mathrm{M}$ sodium citrate for examination under a light microscope at 400-magnification. A total of 3 hundred spermatozoa were examined on each slide (1800 cells in each group $(n=6)$, and the head, tail and total abnormality rates of spermatozoa were recorded as percentage [20].

\section{Biochemical analyses}

The sera and testicular tissue obtained from animals of different treatment groups were subjected to certain biochemical analyses

\section{Determination of oxidative stress indicators in testes}

Lipid peroxidation was measured by estimation of malondialdhyde (MDA) in testes by the method of Okahawa et al. [21]. Reduced glutathione content (GSH) of supernatant was measured by the method of Beutler et al. [22].

\section{Hormonal assay}

Testosterone was estimated by the method described by Yen and Jaffe [23]. Acid phosphates activity was estimated by the method described by Kind and Kind [24]. Fructosamine was estimated by the method described by Johnson et al. [25].

\section{Determination of testicular DNA damage by comet assay}

Testicular DNA damage was evaluated by a single-cell gel electrophoresis (comet) assay as described by Singh et al. [26], $1 \mathrm{~g}$ of crushed samples were transferred to $1 \mathrm{~mL}$ ice-cold PBS. This suspension was blended for $5 \mathrm{~min}$ and filtered. Cell suspension (100 $\mu \mathrm{L}$ ) was mixed with $600 \mu \mathrm{L}$ of low-melting agarose (0.8\% in PBS). 100 $\mu \mathrm{L}$ of this mixture were spread on agarose-precoated slides. The coated slides were immersed in lyses buffer (TBE $(0.045 \mathrm{M}), \mathrm{pH}$ 8.4, which containing $2.5 \% \mathrm{SDS}$ ) for $15 \mathrm{~min}$. The slides were placed in electrophoresis chamber containing the same TBE buffer, but devoid of SDS. The electrophoresis conditions were $2 \mathrm{~V} / \mathrm{cm}$ for $2 \mathrm{hr}$ and $100 \mathrm{~mA}$. The slides were stained with ethidium bromide $(20 \mu \mathrm{g} / \mathrm{mL})$ at $4^{\circ} \mathrm{C}$ and kept under observation with the samples still humid. The DNA fragment migration patterns of 100 cells for each dose level were analyzed using a fluorescence microscope (with excitation filter 420-490 nm (issue $510 \mathrm{~nm}$ )). The comets tails lengths were measured from the middle of the nucleus to the end of the tail with 40X increase for the count and measure the size of the comet. For good visualization of DNA damage, observations are made of EtBr-strained DNA using a
40X objective on a fluorescent microscope. Although any image analysis system may be convenient for the quantitation of SCGE data, we used comet 5 image analysis software developed by kinetic imaging, Ltd. (Liverpool, UK) linked to a CCD camera. To assess the quantitative and qualitative extent of DNA damage in the cells the length of DNA migration and the percentage of migrated DNA were measured. Finally, the program calculates tail moment. Generally, 50 to 100 randomly selected cells are analyzed per sample.

\section{Histopathological examination}

Histopathological examination was done by fixation of Testicular tissue organs in $10 \%$ buffered formalin overnight and then embedded with paraffin. When analyzed was started, all paraffin-embedded tissue was sectioned at $4 \mu \mathrm{m}$, deparaffinized in xylene, dehydrated by ethanol in decreasing concentrations (100, 95 and 70\%) consecutively, and stained with haematoxylin and eosin. These specimens were examined under bright-field optical microscopy using a light microscope and 40X magnification powers. Corresponding digital images were captured and saved for later analysis [27].

\section{Statistical analysis}

Analysis of all data was performed by using SPSS (Version 15) and Results are expressed as Mean \pm S.E. Statistical differences were determined by Duncan test for multiple comparisons after ANOVA. $\mathrm{P}<0.05$ was considered statistically significant.

\section{Results}

\section{Phenolic compound of hot water green tea extract}

As recorded in Table 1, the Total phenol, flavonoid and tannins content of aqueous green tea extract were $340.42,105.86$ and $239 \mathrm{mg} / \mathrm{g}$ DW respectively.

\begin{tabular}{|l|l|l|l|}
\hline \multicolumn{3}{|c|}{ Content of Green Tea Extract } \\
\hline Compound & Total phenol & Flavonoid & Tannins \\
\hline $\mathrm{mg} / \mathrm{g}$ & $340.42 \pm 0.89$ & $105.86 \pm 1.76$ & $239 \pm 2.44$ \\
\hline
\end{tabular}

Table 1: Total phenol, flavonoid and tannins content of hot water green tea extract.

\section{Antioxidant activity of hot water green tea extract}

The antioxidant potential of hot water green tea extract was evaluated using different antioxidant tests, total antioxidant activity and ABTS radical scavenging (Table 2). Hot water green tea extract showed the higher antioxidant activity than control in tests. Hot water green extract showed dose-dependent activity relationships.

\begin{tabular}{|l|l|l|l|l|l|l|l|}
\hline \multicolumn{1}{|c|}{$\begin{array}{c}\text { Total Antioxidant } \\
\text { capacity }\end{array}$} & & & \multicolumn{1}{|c|}{$\begin{array}{c}\text { ABTS free radical scavenging } \\
\text { capacity }\end{array}$} & & \\
\hline Concentration $(\mu \mathrm{g} / \mathrm{mL})$ & 100 & 200 & 300 & Concentration $(\boldsymbol{\mu g} / \mathbf{m L})$ & 50 & 150 & 200 \\
\hline Hot water green tea & $367.23 \pm 1.73$ & $720.97 \pm 2.25$ & $972.12 \pm 1.163$ & Hot water green tea & $42.07 \pm 2.227$ & $72.33 \pm 0.44$ & $90.83 \pm 0.51$ \\
\hline
\end{tabular}


Citation: Afify MM (2018) Thiocyclam-Induced Reproductive Toxicity, Oxidative Stress and Genomic DNA Damage in Testicular Tissues of Rats:

Table 2: Total antioxidant capacity and abts free radical scavenging capacity of hot water green tea extract.

\section{Weight of sexual organs}

The effects of Thiocyclam, GTE and their combination on weights of reproductive organs are summarized in Table 3. It showed no significant difference between tested groups.

\begin{tabular}{|l|l|l|l|}
\hline \multicolumn{4}{|c|}{ Weight of Sexual Organs (g) } \\
\hline Groups & Testes & Epididymes & $\begin{array}{l}\text { Seminal } \\
\text { Vesicles }\end{array}$ \\
\hline Control (C) & $1.074 \pm 0.101$ & $1.860 \pm 0.0907$ & $0.348 \pm 0.0402$ \\
\hline Thiocyclam (ThC) & $1.431 \pm 0.0898$ & $1.402 \pm 0.09$ & $0.626 \pm 0.119$ \\
\hline $\begin{array}{l}\text { Green Tea Extract } \\
\text { (GTE) }\end{array}$ & $1.286 \pm 0.0686$ & $1.560 \pm 0.110$ & $0.558 \pm 0.0325$ \\
\hline
\end{tabular}

\begin{tabular}{|l|l|l|l|}
\hline$($ ThC+GTE $)$ & $1.332 \pm 0.127$ & $1.594 \pm 0.135$ & $0.464 \pm 0.0590$ \\
\hline
\end{tabular}

Table 3: Effects of Thiocyclam (ThC), Green Tea Extract (GTE) and their combination for 65 days on the weight of sexual organs $(\mathrm{g} / 100 \mathrm{~g}$ body wt.).

\section{Sperm characteristics}

As recorded in Table 4, oral administration of Thiocyclam markedly affect sperm quality, as evidenced by a significant reduction in sperm count, sperm motility and increased sperm abnormality. However, these adverse effects of Thiocyclam administration were more alleviated in animals treated with GTE.

\begin{tabular}{|l|l|l|l|c|}
\hline \multicolumn{1}{|c|}{ Groups } & \multicolumn{1}{c|}{ Sperm characteristics } \\
\hline & \multicolumn{1}{|c|}{$\left(\mathbf{1} \mathbf{0}^{6} / \mathrm{ml}\right)$} & \multicolumn{1}{c|}{ Sperm Motility } & Progressive Motility & Abnormalities \\
\hline Control (C) & $104.80 \pm 1.985$ & $68.40 \pm 5.231$ & $(\%)$ & $(\%)$ \\
\hline Thiocyclam (ThC) & $95.20 \pm 2.672^{\mathrm{a}, \mathrm{c}}$ & $34.80 \pm 1.530^{\mathrm{a}, \mathrm{c}, \mathrm{d}}$ & $18.00 \pm 2.345^{\mathrm{a}, \mathrm{c}}$ & $29.00 \pm 1.817$ \\
\hline Green Tea Extract (GTE) & $107.60 \pm 1.72^{\mathrm{b}}$ & $69.80 \pm 4.042^{\mathrm{b}}$ & $27.20 \pm 2.177^{\mathrm{b}}$ & $40.00 \pm 2.864^{\mathrm{a}, \mathrm{c}}$ \\
\hline (ThC+GTE) & $101.60 \pm 1.208^{\mathrm{b}}$ & $61.80 \pm 1.985^{\mathrm{b}}$ & $20.00 \pm 1.581$ & $28.40 \pm 2.561^{\mathrm{b}}$ \\
\hline
\end{tabular}

Table 4: Effects of Thiocyclam (ThC), Green Tea Extract (GTE) and their combination for 65 days on sperm characteristics.

\section{Oxidative stress indicators}

Table 5 shows the influence of Thiocyclam exposure and treatment with GTE on the Oxidative stress indicators MDA and GSH. Thiocyclam administration produces a significant increase in MDA level as compared by control. However, GTE co-administration not attenuates the level of MDA to control values. Meanwhile, GSH content was decreased significantly in ThC-treated group. However, the supplementation of GTE slightly attenuates the significant changes in GSH content.

\begin{tabular}{|l|l|l|}
\hline Groups & MDA & GSH \\
\hline & (nmol/g tissue) & ( $\mu \mathrm{mol} / \mathrm{g}$ tissue) \\
\hline Control (C) & $34.622 \pm 2.217$ & $8.318 \pm 0.530$ \\
\hline Thiocyclam (ThC) & $53.426 \pm 2.105^{\mathrm{a}, \mathrm{c}}$ & $6.548 \pm 0.420^{\mathrm{a}, \mathrm{c}}$ \\
\hline
\end{tabular}

\begin{tabular}{|l|l|l|}
\hline Green Tea Extract (GTE) & $31.734 \pm 2.402^{\mathrm{b}, \mathrm{d}}$ & $9.703 \pm 0.339^{\mathrm{b}, \mathrm{d}}$ \\
\hline (ThC+GTE) & $55.952 \pm 8.293^{\mathrm{a}, \mathrm{c}}$ & $7.160 \pm 0.328^{\mathrm{c}}$ \\
\hline
\end{tabular}

Table 5: Effects of Thiocyclam (ThC), Green Tea Extract (GTE) and their combination for 65 days on Malondialdhyde (MDA) and Reduced Glutathione (GSH) in testicular tissues.

\section{Hormones levels}

Table 6 shows a decrease in serum Testosterone level in ThC-treated group as compared with control group. However, GTE administration produces a non-significant increase of Testosterone level and improves it towards normal values when given to ThC-treated group.

\begin{tabular}{|l|l|l|l|}
\hline Groups & Testosterone & Acid phosphatase & Fructose \\
\hline & (ng/mL) & (U/L) & (U/L) \\
\hline Control (C) & $2.038 \pm 0.061$ & $23.462 \pm 1.381$ & $368.65 \pm 12.263$ \\
\hline Thiocyclam (ThC) & $1.532 \pm 0.166 \mathrm{c}$ & $31.168 \pm 1.089 \mathrm{a,d}$ & $305.584 \pm 16.553^{\mathrm{a}, \mathrm{c}}$ \\
\hline
\end{tabular}


Citation: Afify MM (2018) Thiocyclam-Induced Reproductive Toxicity, Oxidative Stress and Genomic DNA Damage in Testicular Tissues of Rats: Protective Effects of Green Tea Extract. J Environ Anal Toxicol 8: 566. doi:10.4172/2161-0525.1000566

Page 5 of 9

\begin{tabular}{|l|l|l|l|l|}
\hline Green Tea Extract (GTE) & $2.608 \pm 0.264^{\mathrm{b}, \mathrm{d}}$ & $25.530 \pm 2.379$ & $350.716 \pm 5.621^{\mathrm{b}}$ \\
\hline (ThC+GTE) & $1.674 \pm 0.227^{\mathrm{c}}$ & $22.878 \pm 1.538^{\mathrm{b}}$ & $314.824 \pm 4.762^{\mathrm{a}}$ \\
\hline
\end{tabular}

Table 6: Effects of Thiocyclam (ThC), Green Tea Extract (GTE) and their combination for 65 days on serum testosterone, acid phosphatase and fructose levels.

\section{Comet assay result}

Figures 1 and 2 show the effects of Thiocyclam and crude GTE treatments on DNA damage in rat Testicular tissue, using Comet assay Parameters as Comet Tail Length, Tail DNA\% and Tail Moment. Compared to the control values for Comet Tail Length (1.76 um), Tail DNA\% (1.95) and Tail Moment (5.84), Thiocyclam induced a significant elevation $(\mathrm{P}<0.05)$ in the levels of the tested parameters, regardless the repairing and/or the ameliorating effect of GTE supplementation.

\section{Histopathology of testes}

The histopathological examination of testes of control and GTE groups (Figure 3A and 3B), showed a normal histological structure of the mature active seminiferous tubules with complete spermatogenic series in the tubular lumen, while ThC-treated group (Figure 3C) exhibited evident signs of testicular injury such as Wide area of homogenous eosinophilic material was noticed underneath the tunica albuginea as well as in between the seminiferous tubules in the deep zone of the parenchyma. The seminiferous tubules showed degenerative change while the interstitial cells in between had pyknotic nuclei as well as homogenous eosinophilic albuminous material. However, there were degeneration in some few individual seminiferous tubules with pyknosis in the nuclei in some of the interstitial cells in the ThC+GTE treated group (Figure 3D).

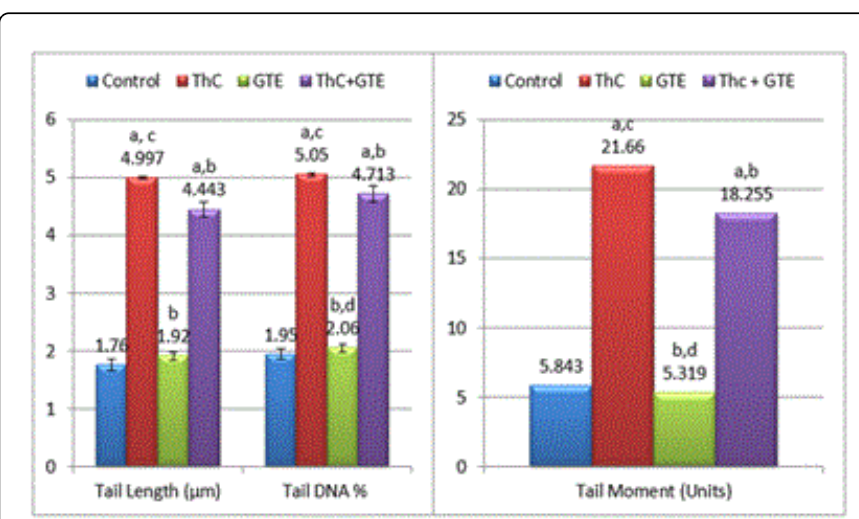

Figure 1: Effects of Thiocyclam (ThC), Green Tea Extract (GTE) and their combination for 65 days on Testicular DNA damage by Comet Assay. All data were expressed as mean \pm SE (Standard Error) of 10 albino rats. Superscript letters; a, b, c, d significance differences versus control, (ThC), (GTE) and (ThC+GTE) Treated groups respectively at $\mathrm{P} \leq 0.05$.

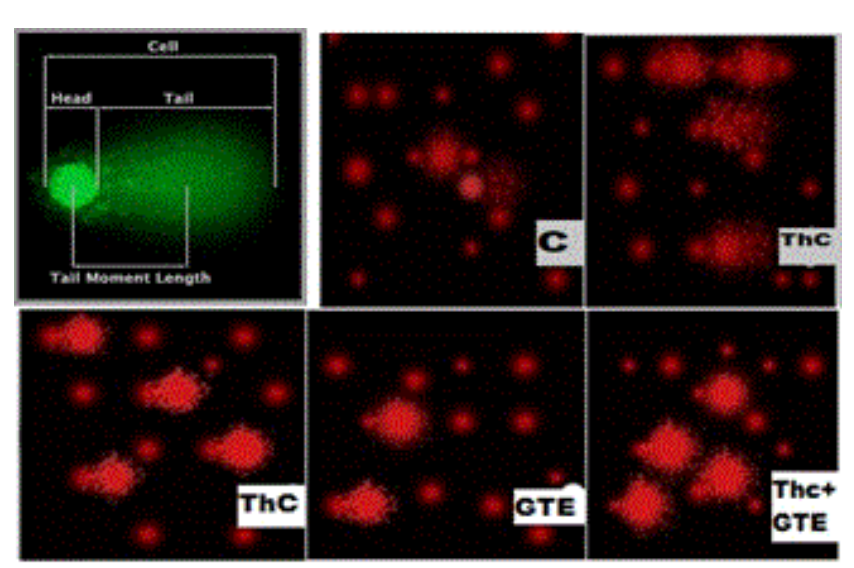

Figure 2: Comet assay images (magnification 40X obj.) of alkaline gel electrophoresis demonstrating DNA damage in Testicular tissues from various examined groups.

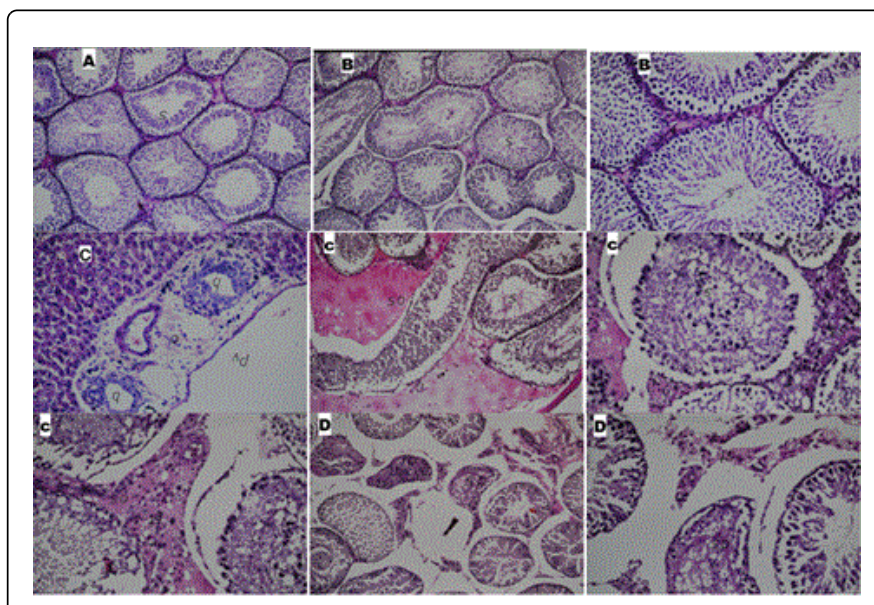

Figure 3: Light microscopic sections of testes from various examined groups, control (A), green tea extract (B), Thiocyclam treated animals (C), and combination ThC+GTE (D) for 65 days. Sections ( $4 \mu \mathrm{m}$ thickness) were stained with haematoxylin-eosin (40X).

\section{Discussion}

Thiocyclam is a broad-spectrum nereistoxin analogue insecticide and it is frequently used in agriculture against a wide range of insects. Studies concerning the effect of Thiocyclam on the reproductive system and infertility are limited. Hence, this study was conducted to evaluate the reproductive toxicity and oxidative status in the testes and also to assess the potential protective effects of green tea extract against 
testicular oxidative stress and DNA damage induced by Thiocyclam in male rats.

Aqueous green tea extract (GTE) prepared from the leaves of Camellia sinensis is contains several polyphenolic components with antioxidant and free radical scavenging properties, mainly flavonoids and catechins which are strong antioxidants [28]. Polyphenols plant limited levels of oxidative stress and reduced the risk of various degenerative diseases [29]. In another study carried out by Al-Ghafari et al. [30], they reported that the polyphenol content of hot green tea was $678.7 \mu \mathrm{g}$ of Gallic acid/10 mg. On the other hand, Pereira et al. [31] found that the hot distilled water green tea total phenol and flavonoid contents were $55.40 \mathrm{mg} / \mathrm{g}$ and $7.31 \mathrm{mg} / \mathrm{g}$, respectively. Total phenol of Hot water green tea from china and Malaysia were $205 \pm 9.9$ $\mathrm{mg} / \mathrm{g}$ and $363 \pm 25 \mathrm{mg} / \mathrm{g}$, respectively and Total antioxidant capacity of hot water green tea from china and Malaysia were $420 \pm 48 \mathrm{mg} / \mathrm{g}$ and $700 \pm 11 \mathrm{mg} / \mathrm{g}$, respectively according to Chan et al. [32]. Hot water green tea had the highest antioxidant activity against ABTS and DPPH radical scavenging [31]. Phenolic compounds of green tea have antioxidant potential by protection against oxidative reactions [33]. In general, previous studies have proven that GTE can be used to protect humans from oxidative stress damage $[12,34,35]$. The strong healthpromoting effect of green tea can be attributed to Green tea polyphenols that scavenge reactive oxygen species (ROS) by generating more stable phenolic radicals. In addition, the radical scavenging ability of (-]-epigallocate epigallocatechin-3-gallate (EGCG), its main polyphenolic catechin constituent [36,37]. In our results, green tea showed more polyphenol and flavonoid contents, higher antioxidant activity and ABTS free radical scavenging capacity than control. These finding run in parallel, with those obtained by Al-Ghafari et al. [30], Pereira et al. [31] and Chan et al. [32].

In the present study, oral administration of ThC induced reproductive toxicity which manifested by lowered semen quantity and quality, as evidenced by a significant reduction in sperm count, sperm motility and increased sperm abnormality. The reduction in sperm count and other semen characteristics may be due to an adverse effect of ThC on spermatogenesis and affected the androgen biosynthesis pathway [38]. Moreover, a lack of testosterone hormone disrupts spermatogenesis as Testosterone is very essential to maintain the structure and function of the testis and male accessory sex gland. These findings are in agreement with the findings conducted by some studies revealed that a reduction in testicular sperm counts, epididymal sperm counts and daily sperm production induced by most of pesticides $[39,40]$. In addition, it was observed that ThC-induced reductions of sperm production, motility and maturation in rats were accompanied by a significant decrease in testosterone level which considered as an indicator of chemical toxicity on reproductive system [41]. Reduction of serum Testosterone clearly explained the inhibitory effect of insecticide on the secretion of pituitary gonadotrophins (FSH and LH) and consecutively on the Testosterone biosynthesis in the testes of rates [42]. Testosterone is essential to maintain the function and structure of the male reproductive accessory gland and any lack of testosterone disrupt spermatogenesis [43].

Previous studies reported that oxidative stress has been implicated to be an important factor in the mechanism of pesticide toxicity. In addition, oxidative stress considered a major factor in the pathogenesis of male infertility [6]. In testes, oxidative damage is capable of disrupting the steroidogenic capacity of Leydig cells as well as the ability of the germinal epithelium to differentiate normal spermatozoa [44,45]. Lipid peroxidation was known to be one of the molecular mechanisms involved in pesticide-induced cytotoxicity. Malondialdehyde (MDA) is a stable end product of lipid peroxidation so, it can be used as an important indicator of lipid peroxidation [46]. A significant increase in the lipid peroxidation (MDA) level and a concomitant decrease in GSH level in testicular tissues following administration of the ThC dose were observed in the present study. Increased MDA in the testicular tissues is indicative of the generation of lipid peroxidation which predisposes cells membrane structure and functional damage. Also, GSH depletion has been shown to intensify lipid peroxidation and predispose cells to further oxidant damage [46]. These results run in parallel with previous studies results that reported insecticide induced lipid peroxidation production in plasma of rats $[40,47,48]$.

In fact, one of the mechanisms of pesticide toxicity is oxidative DNA damage which mediated through oxidative stress, chemical modification of nucleotides, direct action of ROS on DNA, or indirectly by aldehydic lipid peroxidation degradation products $[49,50]$. In the present study, ThC treatment induced testicular DNA damage proved by comet assay which is a simple, rapid and sensitive genotoxicity technique for measuring and analyzing DNA damage and repairing effect in separated cells [51]. The increase of DNA damage in our result is in agreement with data of previous studies which reported similar result following pesticide exposure in humans and experimental animals [52-55]. It was documented that xenobiotic chemicals such as pesticide induce oxidative stress that was demonstrated as elevation of lipid peroxidation and reduction in glutathione content in the testes of rats [56,57], which in turn, participate for more extent to the DNA damage and suggesting the role of oxidative stress and ROS in induction of genotoxicity in our study. ROS left unbalanced by antioxidants (enzymatic) can induce damage to cellular macromolecules and producing single-double strand DNA breaks, purine, pyrimidine, or deoxyribose modifications and DNA crosslink [58,59].

Regarding to the histopathological examination of testes, ThC induced some histopathological changes in the testis and exhibited evident signs of testicular injury such as Wide area of homogenous eosinophilic material was noticed underneath the tunica albuginea as well as in between the seminiferous tubules in the deep zone of the parenchyma. The seminiferous tubules showed degenerative change and disorganized with incomplete spermatogenesis, while the interstitial cells in between had pyknotic nuclei as well as homogenous eosinophilic albuminous material. These histopathological changes may be attributed to ThC-induced direct cytotoxic effect by producing oxidative stress on the seminiferous tubules, through generation of free oxygen radicals, alteration in antioxidants, lipid peroxidation and the reduction in testosterone hormone. Wherein, testosterone is essential for the integrity of different generations of germ cells in seminiferous tubules. Therefore, reduction of testicular testosterone level may lead to sloughing of germ cells from seminiferous epithelium and may induce apoptosis of germ cell and subsequent male infertility [60]. Moreover, the induction of acid phospahatase enzyme activity due to the peri tubular vascular dilatation leading to increase of cell membrane permeability and transphosphorylation disturbance resulting from cellular degeneration that causing inhibition of spermatogenesis [61]. This finding was parallel to the reduction in epididymal sperm count. These lesions are in harmony with man previous investigator who reported that a variable degree of degenerative changes in the seminiferous tubules and Sloughing of germ cells in the lumen of some epididymal ducts indicating testicular dysfunction after exposure to different pesticide [40,62-64]. 
Overall, these findings of our study revealed that GTE supplementation can ameliorate or reverse the toxic effects induced by Thiocyclam. This is shown by a significant but not completely recovery in oxidative stress parameters e.g., a significant reduction in lipid peroxidation and as a consequence of improvement in GSH content. Moreover, improving sperm quality and quantity and serum testosterone level significantly increased parallel to the reduction in lipid peroxidation, highlighting the protective role of GTE against pesticide-induced toxicity. In this respect, a partial reversal of DNA damage is shown by a marked, but not complete recovery in terms of Comet assay parameters e.g., a significant reduction in Comet Tail Length, Tail DNA \% and Tail Moment. Similarly, some of the biochemical deteriorations accompanied by histopathological effects were alleviated following GTE administration. This may be attributed to the potential antioxidant activity and ABTS free radical scavenging capacity of GTE that reduce lipid peroxidation which restoring the integrity of the cell membrane and improve the disturbance in permeability [65-68]. GTE contain mainly polyphenols and catechins which are strong antioxidants, green tea catechins known as an efficient free radical scavenger due to their one electron reduction potential $[69,70]$. In addition, green tea contains selenium, zinc and manganese which act as co-factors in antioxidant enzymes, while polyphenols can chelate and bind to metallic ions such as copper and iron and preventing their participation in oxidation reactions, so this leading to generation of hydroxyl radical, suppress the redox-sensitive transcription factors and the pro-oxidant enzymes, such as inducible nitric oxide synthase (iNOS), cyclooxygenase 2 (COX-2), lipoxygenase 2 (LOX-2) and xanthine oxidase over than stimulate the antioxidant enzymes, such as superoxide dismutases and glutathione Stransferases, highlighting their protective role against pesticideinduced toxicity $[69,71]$.

\section{Conclusion}

In conclusion, our results revealed that subacute exposure to Thiocyclam induce reproductive toxicity in male rates manifested by a significant reduction in sperm count, sperm motility as well as testosterone level, while increased sperm abnormality. Moreover, Thiocyclam leads to a significant oxidative damage as shown by increased in lipid peroxidation and decreased in GSH content and testicular DNA damage evidenced by increase in comet assay parameters. The histological examination of testes revealed degenerative change and disorganization of seminiferous tubules with incomplete spermatogenesis. On the contrary, GTE played a potential protective effect against Thiocyclam induced reproductive and oxidative stress by improving the oxidative status and partly alleviating and restoring the oxidative DNA damage, as well as the testicular histological damage, highlighting the protective and therapeutic potentiality of green tea against pesticide-induced reproductive toxicity and its health benefits.

\section{References}

1. Alexandratos N, Bruinsma J (2012) World agriculture towards 2030/2050: the 2012 revision. ESA Working Paper No. 12-03, 2012, FAO, Rome.

2. Tago D, Andersson H, Treich N (2014) Pesticides and health: A review of evidence on health effects, valuation of risks, and benefit-cost analysis. Adv Health Econ Health Serv Res 24: 203-295.

3. Sharma P, Ul Huq A, Singh R (2014) Cypermethrin-induced reproductive toxicity in the rat is prevented by resveratrol. J Human Rep Sci 7: 99-106.
4. Rani A, Sahai A, Srivastava AK, Rani A (2007) Carbaryl induced histopathological changes in the testis of albino rats. J Anatom Society India 56: 4-6.

5. Presibella KM, Kita DH, Carneiro CB, Andrade AJ, Dalsenter PR (2005) Reproductive evaluation of two pesticides combined (deltamethrin and endosulfan) in female rats. Reprod Toxicol 20: 95-101.

6. Rastogi SK, Satyanarayan PV, Ravishankar D, Tripathi S (2009) A study on oxidative stress and antioxidant status of agricultural workers exposed to organophosphorus insecticides during spraying. Indian J Occup Environ Med 13: 131-134.

7. Milatovic D, Gupta RC, Aschner M (2006) Anticholinesterase toxicity and oxidative stress. Sci World J 28: 295-310.

8. Muniz JF, McCauley L, Scherer J, Lasarev M, Koshy M, et al. (2008) Biomarkers of oxidative stress and DNA damage in agricultural workers: a pilot study. Toxicol Appl Pharmacol 227: 97-107.

9. Chengelis CP, Kirkpatrick JB, Regan KS, Radovsky AE, Beck MJ, et al. (2008) 28-Day oral(gavage) toxicity studies of green tea catechins prepared for beverages in rats. Food Chem Toxicol 46: 978-989.

10. Anderson RF, Fisher LJ, Hara Y, Harris T, Mak WB, et al. (2001) Green tea catechins partially protect DNA from $\mathrm{OH}$ radical-induced strand breaks and base damage through fast chemical repair of DNA radicals. Carcinogenesis 22: 1189-1193.

11. Ware GW, Whitacre DM (2004) The Pesticide Book. Meister Media Worldwide Willoughby, Ohio, p: 496.

12. El-Beshbishy HA (2005) Hepatoprotective effect of green tea (Camellia sinensis) extract against tamoxifen-induced liver injury in rats. J Biochem Mol Biol 38: 563-570.

13. Mehana EE, Meki AR, Fazili KM (2012) Ameliorated effects of green tea extract on lead induced liver toxicity in rats. Exp Toxicol Pathology 64: 291-295.

14. Tambe VD, Bhambar SR (2014) Estimation of total phenol, tannin, alkaloid and flavonoid in Hibiscus Tiliaceus Linn. wood extracts. Research and Reviews: J Pharm Phytochem 2: 41-47.

15. Prieto P, Pineda M, Aguilar M (1999) Spectrophotometric quantitation of antioxidant capacity through the formation of a phosphomolybdenum complex: specific application to the determination of vitamin E. Anal Biochem 269: 337-341.

16. Arnao MB, Cano A, Acosta M (2001) The hydrophilic and lipophilic contribution to total antioxidant activity. Food Chem 73: 239-244.

17. Sarkar R, Mohanakumar KP, Chowdhury M (2000) Effects of an organophosphate pesticide, quinalphos, on the hypothalamo-pituitarygonadal axis in adult male rats. J Reprod Fert 118: 29-38.

18. Weil CS (1952) Tables for convenient calculation of median effective dose (ED50 or LD50) and instructions in their use. Biometrics 8: 249.

19. Uzunhisarcikli M, Kalender Y, Dirican K, Kalender S, Ogutcu A, et al. (2007) Acute, subacute and subchronic administration of methyl parathion-induced testicular damage in male rats and protective role of vitamins C. and E. Pest Biochem Physiology 87: 115-122.

20. Turk G, Atessahin A, Sonmez M, Ceribasi AO, Yuce A (2008) Improvement of cisplatin-induced injuries to sperm quality, the oxidantantioxidant system, and the histologic structure of the rat testis by ellagic acid. Fertil Steril 89: 1474-1481.

21. Okahawa H, Ohishi N, Yagi K (1976) Assay for lipid peroxides in animal tissues by thiobarbituric acid reaction. Anal Biochem 95: 351-358.

22. Beutler ED, Duron O, Kelly MB (1963) Improved method for the determination of blood glutathione. J Lab Clin Med 61: 882-888.

23. Yen SS, Jaffe RB (1978) Determination of plasma testosterone by radioimmunoassay technique. Reprod Endocrinol 33: 122-125.

24. Kind PR, Kind EJ (1954) Estimation of Plasma Phosphatase by Determination of Hydrolysed Phenol with Amino-antipyrine. J Clin Path 7: 322 .

25. Johnson RN, Metcalf PA, Baker JE (1982) In vitro determination of fructosamine in serum. Clinic Chem Acta 127: 87-95. 
26. Singh NP, McCoy M, Tice RR, Schneider EL (1988) A simple technique for quantitation of low levels of DNA damage in individual cells. Exp Cell Res 175: 184-191.

27. Banchroft JD, Stevens A, Turner DR (1996) Theory and practice of histological techniques. 4th edn. Churchil Livingstone, New York.

28. Coimbra S, Castro E, Rocha-Pereira P, Rebelo I, Rocha S, et al. (2006) The effect of green tea in oxidative stress. Clin Nutr 25: 790-796.

29. Pandey BK, Rizvi IS (2009) Plant polyphenols as dietary antioxidants in human health and disease. Oxidative Medicine and Cellular Longevity 2: 270-278.

30. Al-Ghafari BA, Shorbaji MA, AL-Sarori AL, Baduwailan OE, Basaar AA, et al. (2016) Phenolic Contents and Antioxidant Activities of Green Tea with and without Lemon. Nat Sci 8: 247-255.

31. Pereira VP, Knor FJ, Vellosa JC, Beltrame FL (2014) Determination of phenolic compounds and antioxidant activity of green, black and white teas of Camellia sinensis (L.) Kuntze, heaceae. Rev Bras Pl Med Campinas 16: 490-498.

32. Chan EWC, Soh EY, Tie PP, Law YP (2011) Antioxidant and antibacterial properties of green, black, and herbal teas of Camellia sinensis. Pharmacog Res 3: 266-272.

33. Miguel MG (2010) Antioxidant activity of medicinal and aromatic plants. A review. Flavour Fragr J 25: 291-312.

34. Bushman JL (1998) Green tea and cancer in humans: a review of the literature. Nutr Cancer 31: 151-159.

35. Mahaboob KS, Kour G (2007) Subacute oral toxicity of chlorpyriphos and protective effect of green tea extract. Pest Biochem Physil 89: 118-123.

36. Elbling L, Weiss RM, Teufelhofer O, Uhl M, Knasmueller S, et al. (2005) Green tea extract and (-)-epigallocatechin-3-gallate, the major tea catechin, exert oxidant but lack antioxidant activities. FASEB J 7: 807-809.

37. Shi XL, Ye JP, Leonard SS, Ding M, Vallyathan V, et al. (2000) Antioxidant properties of (-)-epicatechin-3-gallate and its inhibition of $\mathrm{Cr}$ (VI)induced DNA damage and $\mathrm{Cr}(\mathrm{IV})$ - or TPA-stimulated NF-kappa B activation. Mol Cell Biochem 206: 125-132.

38. Joshi SC, Mathur R, Gulati N (2007) Testicular toxicity of chlorpyrifos (an organophosphate pesticide) in albino rat. Toxicol Ind Health 23: 439-444.

39. Mosbah R, Boulakoud MS, Chouabia A, Yousef MI (2008) Lorsbaninduced changes in haematological parameters, testosterone and thyroxin levels, and semen quality of male rats. Revue Synthèse 18: 35- 44.

40. Odaa SS, El-Maddawy ZK (2012) Protective effect of vitamin E and selenium combination on deltamethrin-induced reproductive toxicity in male rats. Experimental and Toxicologic Pathology 64: 813-819.

41. Yoshida M, Kitani T, Takenaka A, Kudoh K, Katsuda SI, et al. (2002) Lack of effects of oxolinic acid on spermatogenesis in young male adult and aged Wistar rats. Food Chem Toxicol 40: 1815-1825.

42. Chargui I, Haouem S, Haouas Z, Zaouali M, Bencheikh H (2009) Toxic responses to deltamethrin low doses on gonads, sex hormones and lipoperoxidation in male rats following subcutaneous treatments. J Toxicol Sci 34: 663-670.

43. Broockfor FR, Blake CA (1997) Chronic administration of 4-tertoctylphenol to adult male rats causes shrinkage to the testes and male accessory sex organs, disrupts spermatogenesis, and increases the incidence of sperm deformities. Biol Reprod 57: 267-277.

44. Hales DB, Allen JA, Shankara T (2005) Mitochondrial function in Leydig cell steroidogenesis. Ann N Y Acad Sci 1061: 1204.

45. Naughton CK, Nangia AK, Agarwal A (2001) Pathophysiology of varicoceles in male infertility. Hum Reprod Update 7: 473-481.

46. Maellaro F, Casini AF, Dell Bello B, Comporti M (1990) Lipid peroxidation and antioxidant systems in the liver injury produced by glutathione depleting agents. Biochem Pharmacol 39: 1513-1521.

47. El-Gohary M, Awara WM, Nassar S, Hawas S (1999) Deltamethrininduced testicular apoptosis in rats: the protective effect of nitric oxide synthase inhibitor. Toxicology 132: 1-8.
48. Rehman H, Ali M, Atif F, Kaur M, Bhatia K, et al. (2006) The modulatory effect of deltamethrin on antioxidants in mice. Clin Chem Acta 369: 61-65.

49. Collins AR (1999) Oxidative DNA damage, antioxidants, and cancer. Bioassays 21: 238-246.

50. Cicchetti R, Argentin G (2003) The role of oxidative stress in the in vitro induction of micronuclei by pesticides in mouse lung fibroblasts. Mutagenesis 18: 127-132.

51. Collins AR, Ai-guo M, Duthie SJ (1995) The kinetics of repair of oxidative DNA damage (strand breaks and oxidized pyrimidines) in human cells. Mutat Res 336: 69-77.

52. Mahboob M, Rahman MF, Danadevi K, Saleha Banu B, Paramjit G (2002) Detection of DNA damage in mouse peripheral blood leukocyte by the Comet assay after oral administration of Monocrotophos. Drug Chem Toxicol 25: 65-74.

53. Rahman MF, Mahboob M, Danadevi K, Saleha Banu B, Paramjit G (2002) Assessment of genotoxic effects of chloropyriphos and acephate by the comet assay in mice leucocytes. Mut Res 516: 139-147.

54. Shahin S, Ebrahim A, Rohollah H, Samideh K, Shamileh F, et al. (2005) Evaluation of oxidative stress and genotoxicity in organophosphorus insecticide formulators. Hum Exp Toxicol 24: 439-445.

55. Prabhavathy DG, Shaik AP, Jamil K (2006) Cytotoxicity and Genotoxicity Induced by the Pesticide Profenofos on Cultured Human Peripheral Blood Lymphocytes. Drug Chem Toxicol 29: 313-322.

56. Ogutcu A, Suludere Z, Kalender Y (2008) Dichlorvos-induced hepatotoxicity in rats and the protective effects of vitamins $\mathrm{C}$ and $\mathrm{E}$. Environ Toxicol Pharmacol 26: 355-361.

57. Possamai FP, Fortunato JJ, Feier G, Agostinho FR, Quevedo J, et al. (2007) Oxidative stress after acute and sub-chronic malathion intoxication in Wistar rats. Environ Toxicol Pharmacol 23: 198-204.

58. Dizdaroglu M (1992) Oxidative damage to DNA in mammalian chromatin. Mutat Res 275: 331-342.

59. Demple B, Harrison L (1994) Repair of oxidative damage to DNA: enzymology and biology. Annual Rev Biochem 63: 915-948.

60. Kumar SG, Narayana K, Bairy KL, D'Souza UJA, Samuel VP, et al. (2006) Dacarbazine induces genotoxic and cytotoxic germ cell damage with concomitant decrease in testosterone and increase in lactate dehydrogenase concentration in the testis. Mutat Res 607: 240-252.

61. Gawish AM (2010) The Protective Role of Alpha Lipoic Acid Against Pesticides Induced testicular toxicity. Histopathological and Histochemical Studies. J Aquac Res Development 1: 101.

62. Ikpeme EV, Okonko LE, Udensi OU (2016) Detrimental Effects of Chlorpyrifos and Cypermethrin on Reproductive Physiology of Male Albino Rats. Research Journal Environ Toxicol Res 10: 68-74.

63. Joshi SC, Bansal B, Jasuja ND (2011) Evaluation of reproductive and developmental toxicity of cypermethrin in male albino rats. Toxicol Environ Chem 93: 3.

64. Mahgoub AA, El-Medany AH (2011) Evaluation of chronic exposure of the male rat reproductive system to the insecticide methomyl. Pharmacol Res 44: 73-80.

65. Sato K, Sueoka K, Tanigaki R, Tajima H, Nakabayashi A, et al. (2010) Greentea extracts attenuate doxorubicin-induced spermatogenic disorders in con-junction with higher telomerase activity in mice. J Assisted Reprod Genet 27: 501-508.

66. Kalender Y, Kaya S, Durak D, Uzun FG, Demir F (2012) Protective effects of catechin and quercetin on antioxidant status, lipid peroxidation and testis-histoarchitecture induced by chlorpyrifos in male rats. Environ Toxicol Pharmacol 33: 141-148.

67. Heikal TM, Mossa AH, Abdel rasoul MA, Marei GIK (2013) The ameliorating effects of green tea extract against cyromazine and chlorpyrifos induced liver toxicity in male rats. Asian J Pharm Clin Res 6: 48-55.

68. Heikal TM, Mossa AH, Ibrahim AW, Abdel-Hamid HF (2014) Oxidative Damage and Reproductive Toxicity Associated with Cyromazine and 
Citation: Afify MM (2018) Thiocyclam-Induced Reproductive Toxicity, Oxidative Stress and Genomic DNA Damage in Testicular Tissues of Rats: Protective Effects of Green Tea Extract. J Environ Anal Toxicol 8: 566. doi:10.4172/2161-0525.1000566

Page 9 of 9

Chlorpyrifos in Male Rats: The Protective Effects of Green Tea Extract. Res J Environ Toxicol 8: 53-67.

69. Frei B, Higdon JV (2003) Antioxidant activity of tea polyphenols in vivo: evidence fromanimal studies. J Nutrition 133: 3275S-3284S.
70. Dubick MA, Omaye ST (2007) Grape wine and tea polyphenolics in the modulation of atherosclerosis and heart disease. Nutraceutical Handbook, 2nd edn. CRC.

71. Cabrera C, Artacho R, Giménez R (2006) Beneficial effects of green tea--a review. J Am Coll Nutr 25: 79-99. 